\title{
Clinical symptoms of rat acute peritonitis model and study over effects of oral strontium ranelate administration for the treatment
}

\section{Rat, akut peritonit modelinde klinik semptomlar ve hastalığın tedavisine oral strontium ranilat uygulamalarının etkilerinin araştırılması}

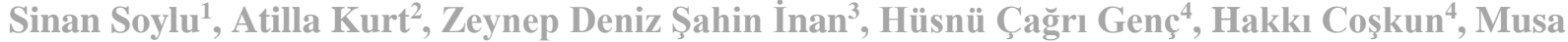 \\ Serin $^{4}$
}

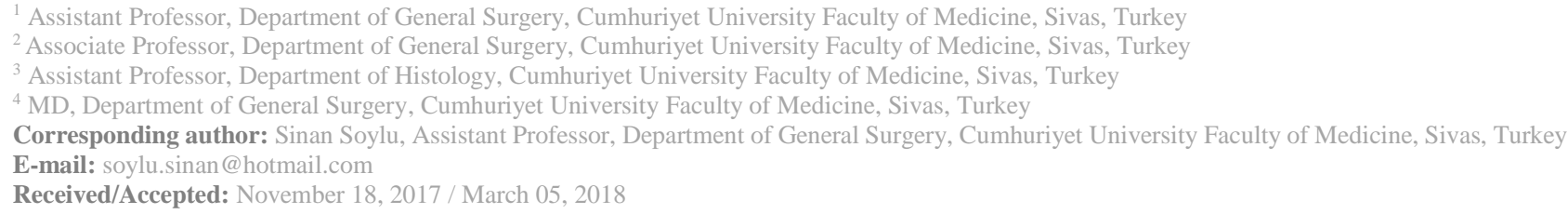

\section{SUMMARY}

Objective: Despite the improvements in the treatments of surgical and intensive care, sepsis and systemic inflammatory response syndrome are the most common cause of mortality. Therefore in the experimental animal model, we aimed to reveal biochemical and histopathologic effects of strontium ranelate on healing in experimental animal model for peritonitis and sepsis.

Method: 20 female Wistar-Albino rats were used.Rats were seperated into 4 groups; control, sham [ceacum ligation perforation $(\mathrm{CLP})], \mathrm{CLP}+$ Strontium $(\mathrm{S})(\mathrm{CLP}+\mathrm{S})$ and S+CLP+S. Rats were euthanised on 7 th day. Peritoneal inflammation staging and ileum resection was performed. Blood samples were taken for biochemical screening and IL1, IL-6, IL-10 and TNF-alpha tests were evaluated.

Results: Peritoneal inflammation score was the highest at CLP group and the lowest at control group. There was healing in CLP+S group compared to CLP group, and more healing in S+CLP+S group compared to CLP+S group. According to histopathological evaluation, ileum injury was the lowest in the control group and the highest in CLP group. Less injury was found in CLP+S group compared to CLP group, and less injury was found in S+CLP+S group compared to CLP+S group. No difference was found when TNF-alpha, IL-1, IL-6 and IL-10 values were compared.

Conclusions: Strontium ranelate may reduce mortality and morbidity by prophylactic treatment in patients at risk of sepsis and patients with sepsis.

Keywords: Peritonitis, sepsis, ceacum ligation perforation, strontium

\section{ÖZET}

Amaç: Cerrahi ve yoğun bakım tedavilerinde ki gelişmelere rağmen sepsis ve sistemik inflamatuar cevap sendromu(SIRS) yetişkin yoğun bakım ünitelerinde ensık ölüm sebeplerindendir. Bu sebeple peritonit ve sepsis için deney hayvanı modelinde stronsiyum ranilat'ın iyileşme üzerine etkisini biyokimyasal ve histopatolojik olarak ortaya koymayı amaçladik

Yöntem: Wistar-Albino cinsi 40 adet dişi sıçan kullanıldı. Sıçanlar; kontrol, sham[çekum ligasyon perforasyon(ÇLP)], ÇLP + Stronsiyum(S) ve S + ÇLP + S olmak üzere 4 gruba ayrıldı. Siçanlar 7. günde ötanazi uygulandı. Peritoneal 
inflamasyon evrelemesi yapıldı. Patoloji için ileum rezeksiyonu yapıldı, biokimyasal inceleme için kan örnekleri alınarak IL-1, IL-6, IL- 10 ve TNF-alpha, bak1ld1.

Bulgular: Peritoneal inflamasyon skoru en düşük kontrol grubunda, en yüksek CLP grubunda bulundu. ÇLP+S grubunda ÇLP grubuna göre iyileşme, $\mathrm{S}+\mathrm{C} L \mathrm{LP}+\mathrm{S}$ grubunda ise ÇLP+S grubuna göre daha fazla iyileşme vardı. Histopatolojik değerlendirmeye göre de incebarsak hasarı en düşük kontrol grubunda, en yüksek ÇLP grubunda bulundu. ÇLP+S grubunda ÇLP grubuna göre daha hafif hasar, $\mathrm{S}+\mathrm{C} \mathrm{LP}+\mathrm{S}$ grubunda ise ÇLP+S grubuna göre daha hafif hasar vardı. TNF$\alpha$, IL-1, IL-6 ve Il-10 değerleri karşılaşıtırıldığında fark yoktu.

Sonuç: Stronsiyum ranilat sepsis riski olan ve sepsis gelişmiş hastalarda proflaktik tedavi ile mortalite ve morbiditeyi azaltabilir.

Anahtar sözcükler: Peritonit, sepsis, çekum ligasyon perforasyon, stronsiyum

\section{INTRODUCTION}

Intra-abdominal infections (ICD) are major cause of morbidity and mortality in intensive care, particularly in patients undergoing surgery. ${ }^{1}$ ICD's are caused by the inflammatory response of the peritoneum against microorganisms and their various structure and toxins and have two common types; peritonitis and intra-abdominal abscess(IA). If the infection is localized, peritonitis is locally limited. If immunity is insufficient, mortality rates come to \%70-90 by generalised peritonitis, systemic inflammatory response syndrome (SIRS) and septic shock. ${ }^{2}$

Strontium chloride or ranilate is a compound that its positive effect on inflammation has been shown. Studies have shown that it is effective against allergic rhinitis and ulcerative cholitis. ${ }^{3}$ It is also used in osteoporosis and pain related to bone metastasis. $^{4,5}$ Recently it has been shown that strontium inhibits inflammatory mediators by TNF-alpha blockage. ${ }^{6-8}$

Ceacal ligation and perforation is the most common model for experimental sepsis at rats and is thought to be a gold standard. ${ }^{9}$

In this study, we aimed to investigate biochemical and histopathologic findings of peritonitis by performing cecal ligation and perforation in rats, revealing the natural process of peritonitis and healing of peritonitis strontium, and also the effect of peritonitis and intraabdominal abscess when applied before peritonitis formation.

\section{MATERIAL AND METHODS}

Experimental study was carried out at the Laboratory Animal Laboratory of Cumhuriyet University. The study started with the approval of Cumhuriyet University Experimental Animals Local Ethics Committee (25.12.2014 issue: 65202830/170). Forty female Wistar-Albino rats weighing 150-230 gr for 4-5 months were used in the study. The rats were maintained under standard environmental conditions $\left(22^{\circ} \mathrm{C}\right.$ temperature, $65 \%$ humidity and 12 hours darkness- 12 hours light). All rats were fasted 18 hours before the start of the experiment, but water was allowed to drink for the last 20 minutes. Rats were randomly divided into four groups of five in each group, taken in separate cages.

\section{Ceacal Ligation and Perforation}

Rats were anesthetized with ketamine (30 mg / kg) $\left(\operatorname{Ketalar}^{\circledR} 50 \mathrm{mg} / \mathrm{ml}\right.$ Pfiser ilaç A.Ş İstanbul) and xylazine $\left(6 \mathrm{mg} / \mathrm{kg}\right.$ ) (Rompun ${ }^{\circledR} \% 2$ Bayer Türk Kimya San. Ltd. Şti. İstanbul) and $2 \mathrm{~cm}$ midline incision was performed. Then the ceacum was removed from the abdomen and ligated with 3/0 silk and drilled twice with a $22 \mathrm{G}$ needle.

\section{Study design}

Rats were divided into 4 groups. Only laparatomy was applied in Group 1. Group 2 received only saline into abdomen, group $3,40 \mathrm{mg} / \mathrm{kg}$ stronsium $\left(\right.$ Protelos $^{\circledR} 2$ gr Oral granule Servier İlaç ve Araştırma A.Ş. Maslak, İstanbul) was started by oral gavage 5 days before peritonitis was formed and continued for 7 days after peritonitis. In group 4 , after peritonitis was performed, oral gavage method was applied for 7 days with $40 \mathrm{mg} / \mathrm{kg}$ stronsium. was established.

On the seventh day, rats were euthanized with a high dose of pentothal sodium. Peritoneal inflammation was staged. Resection for pathology was performed. Blood samples were taken for biochemical examination and IL-1, IL-6, IL-10 and TNF-alpha were analyzed.

\section{Peritoneal İnflammation grading:}

After rats were euthanized, laparotomy was performed from the old incision and the peritoneal inflammation grade was assessed according to Simon et al.'s grading. ${ }^{9}$ (Table 1 ) 
Table 1: Peritoneal inflammation Grading ${ }^{9}$

\begin{tabular}{|l|l|}
\hline Grade & Finding \\
\hline Grade 0 & No inflammation \\
\hline Grade 1 & Well bordered abscess, less free peritoneal fluid \\
\hline Grade 2 & $\begin{array}{l}\text { Well bordered abscess, small amount of free peritoneal fluid, patchy cecum } \\
\text { wall necrosis foci. }\end{array}$ \\
\hline Grade 3 & $\begin{array}{l}\text { Less localized inflammatory reaction, a moderate amount of free peritoneal } \\
\text { fluid, gangrenous cecum }\end{array}$ \\
\hline Grade 4 & $\begin{array}{l}\text { much bloody fluid In the peritoneal cavities, gangrene and bloody fluid on the } \\
\text { cuff wall, perforated caecum }\end{array}$ \\
\hline
\end{tabular}

\section{Histopathological evaluation:}

After rats were euthanized, laparotomy was performed in the old incision and the ileal tissues were resected and fixed in $10 \%$ buffered neutral formalin and allowed to stay for 24-48 hours. Then routine histological follow-up was performed and the tissue was embedded in paraffin blocks. Sections of approximately $5 \mu \mathrm{m}$ thickness were obtained from the obtained paraffin blocks with microtomes (Leica RM2235, Germany). The obtained sections were evaluated by staining with hematoxylen-eosin ( $\mathrm{H} \& \mathrm{E})$. All sections (at least 4 sections for each tissue) were examined; sections with significant artefacts due to dyeing were excluded from the evaluation. All of the preparations prepared after dyeing are complete, in light microscopy (Olympus BX-51 Tokyo, Japan) for the presence of injury to the small bowel. The small intestine injury was graded over a total of 5 degrees, taking into account the scoring system determined by Chiu.$^{10}$ (Table 2 )

Table-2. Histopathological evaluation of the small intestine, Chiu score ${ }^{11}$

\begin{tabular}{|l|l|}
\hline Score & \multicolumn{1}{|c|}{ Finding } \\
\hline $\mathbf{0}$ & Normal mucosa \\
\hline $\mathbf{1}$ & Subepithelial spaces in villus tips \\
\hline $\mathbf{2}$ & Epithelial spaces in villus tips and moderate epithelium separation \\
\hline $\mathbf{3}$ & $\begin{array}{l}\text { Massive epithelial detachment in the lower parts of the villus and spillage at } \\
\text { some tips }\end{array}$ \\
\hline $\mathbf{4}$ & Spillage in Villus, dilate capillaries \\
\hline $\mathbf{5}$ & Disintegration of lamina propria \\
\hline
\end{tabular}

\section{Biochemical analyse:}

IL-1, IL-6, IL-10 AND TNF-alpha levels of the rats were measured by ELISA using a commercial kit according to the company's instructions (eBioscience, Austria).

\section{Statistical Evaluation:}

Statistical Package of Social Sciences 23 (SPSS 23.0, Chicago, IL, USA) program was used. MannWitney $\mathrm{U}$ test was used in the analysis of the data. Statistical significance was accepted as $\mathrm{p}<0.05$.

\section{RESULTS}

\section{Peritoneal İnflammation Grading:}

According to Simon et al.'s rating; CLP group results were statistically significant between the other groups ( $\mathrm{p}<0.05)$ The peritoneal inflammation score was significantly higher in the caecum ligation perforation group compared with the strontium-treated CLP + strontium and strontium + CLP + strontium groups $(p<0,059$. There were no difference between Strontium + CLP and Atronsium + CLP + strontium groups. (Figure 1) 


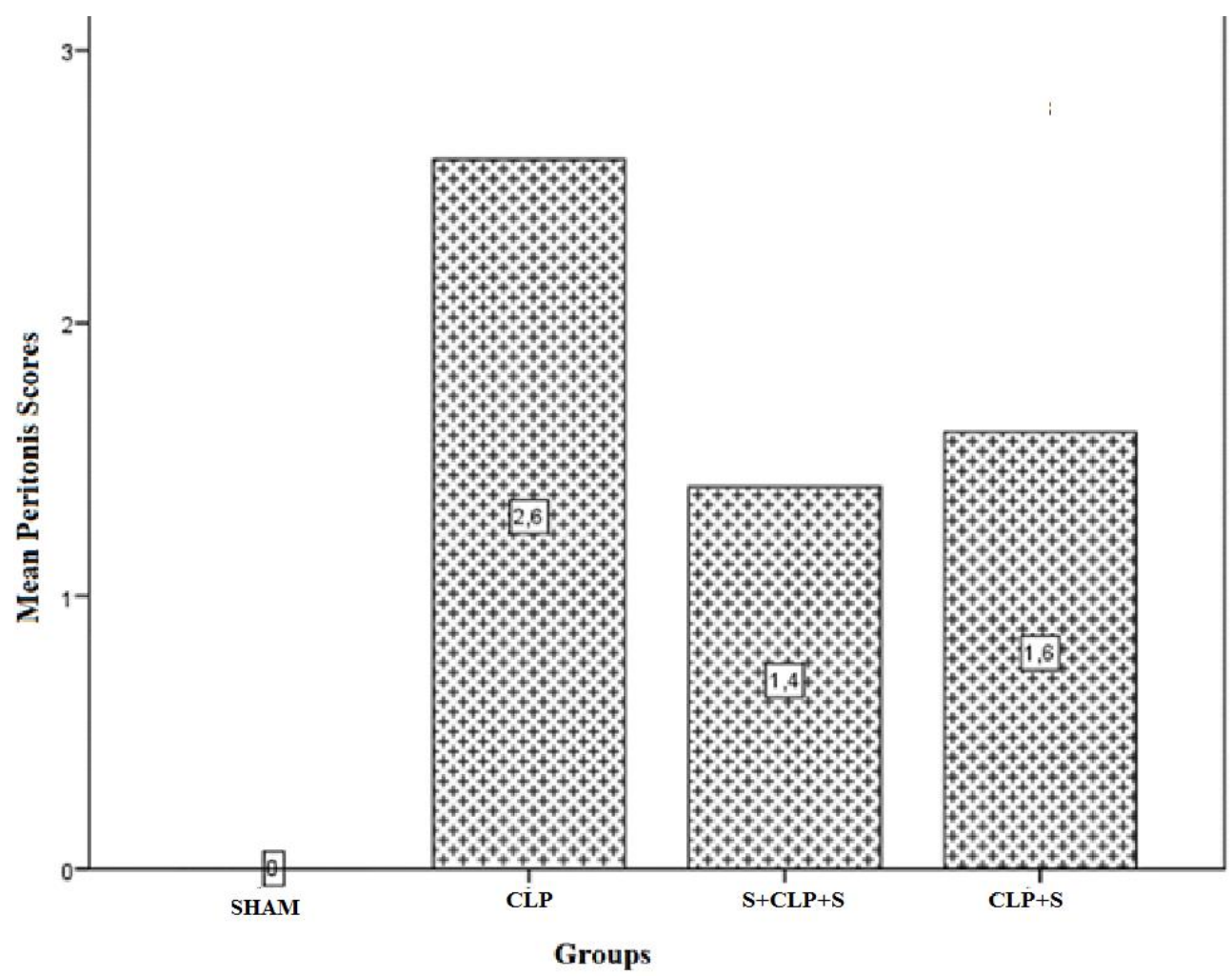

Figure 1. Median peritonitis evaluation score

CLP: Laparatomi, CLP: Ceacal ligation and perforation, S+CLP+S:

\section{Histopathological Evaluation}

The small bowel injury was graded over a total of 5 degrees, considering the scoring system determined by Chiu (Table 2). The score of the control group was statistically lower than the other groups $(p<0,05)$, whereas the score of cecum ligation perforation group was significantly higher than the other groups $(p<0,05)$. Treatment with strontium ranilate after cecal ligation perforation showed significant histopathologic improvement ( $\mathrm{p}<0.05$ ). Postoperative strontium therapy, which was started preoperatively, provided significant histopathologic improvement only after postoperative treatment $(p<0,059)$. (Figure 2 and $3)$. 


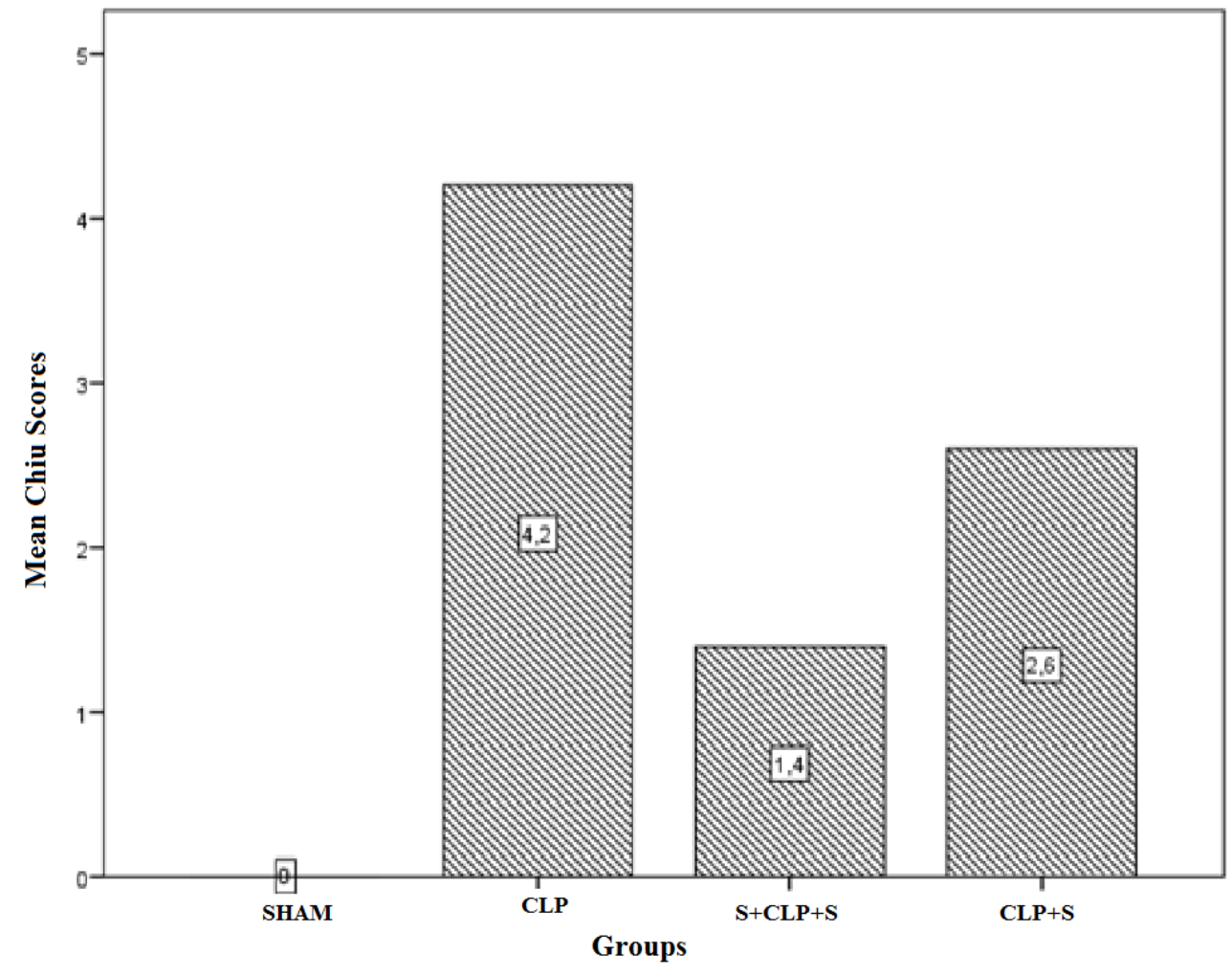

Figure 2. Median Chiu scores
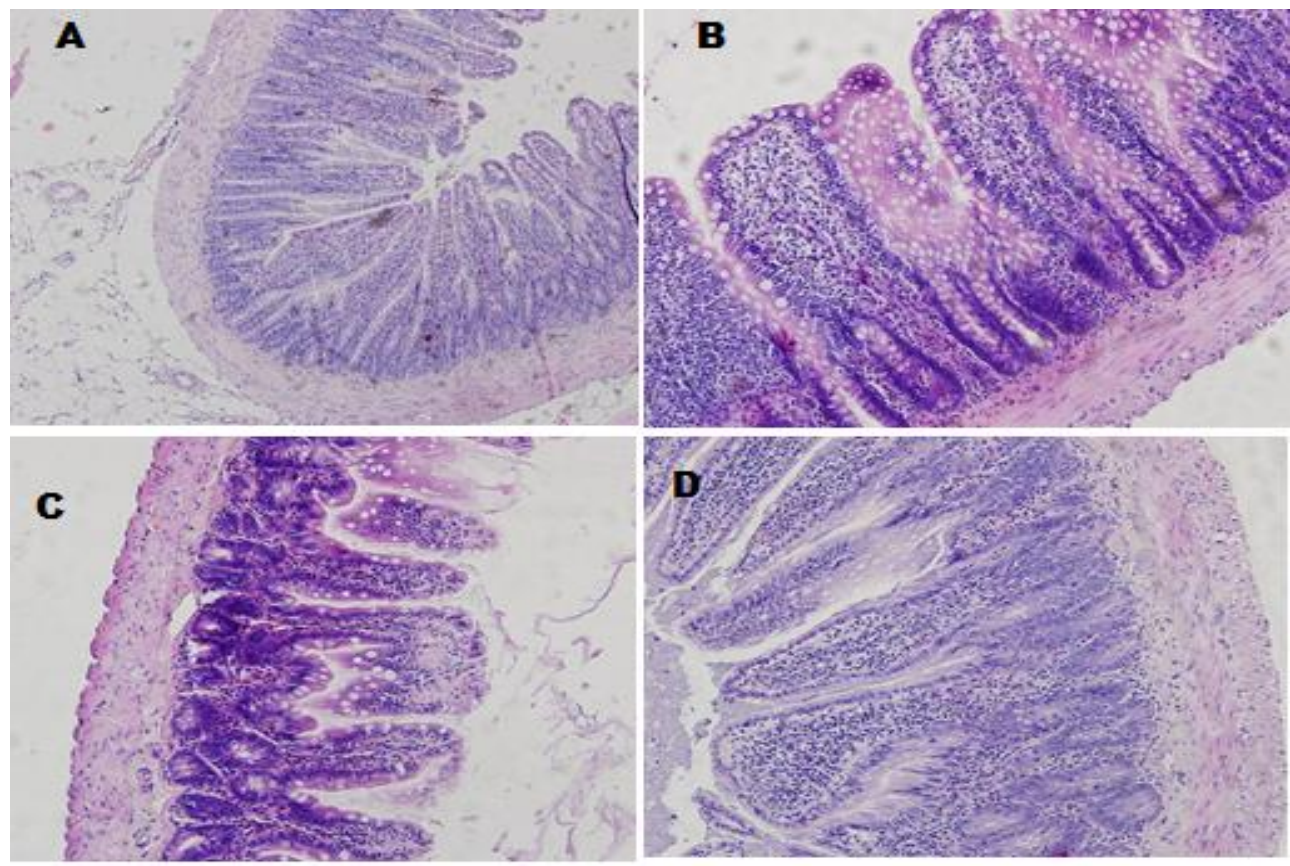

Figure 3.

A: Control Group (10x): The lamina propria of the tunica mucosa shows a proper placement. It is observed that the epithelium that surrounds the villi and villi is normal.

B: CLP Group (20x): Spillage in villus and enlargement with deterioration of lamina propria integrity, inflammation and dilate capillaries in lamina propria are observed.

C: CLP+Strontium Ranilate Group (20x): With the loss and degradation areas of bleeding in the lamina propria of the villi integrity and inflammatory cells are monitored. Compared with the CLP group, less injury was detected in the mucosa layer. Although there is more bleeding area in the lamina propria, it is seen that the villi are not completely detached and the lamina propria at the base of the villi is more regular.

D: Strontium Ranilate +CLP+ Strontium Ranilate Group (20x): Spillage in the villus and a regular lamina propria layer are observed. The villus width is higher in this group compared to the control but less than the CLP + S group. 


\section{Biochemical analysis:}

When TNF- $\alpha$, IL-1, IL- 6 and IL-10 values were compared statistically, there was no difference between the groups ( $p>0.05$ ).

\section{DISCUSSION}

Despite improvements in surgery and intensive care, sepsis and systemic inflammatory response syndrome (SIRS) are the most common causes of death in adult intensive care units ${ }^{11}$. Sepsis and SIRS that occur during the course of peritonitis are mainly associated with the severity of proinflammatory and antiinflammatory products including endotoxin, IL-6 and TNF-alpha which are produced in tissues. ${ }^{12}$ Multiorgan failure, a consequence of released inflammatory mediators, leads to a high mortality rate in peritonitis. Following the acute inflammation of the peritoneum, chemotactic mechanisms lead to cell migration, mostly from the macrophage, to the injured site. These macrophages, activated by plasmin, produce TNF- $\alpha$, IL-1, which are important factors in wound healing. ${ }^{13}$

Caecal ligation and perforation in rats have been most commonly used as experimental sepsis models and are currently considered gold standard in sepsis studies. ${ }^{8}$ In our study, peritoneal score and intestinal injury were found statistically significant in the ligation perforation group compared to the control group $(\mathrm{p}<0,05)$.

Strontium ranilate studies have shown that it is effective on allergic rhinitis, ulcerative colitis. TNF-alpha blockade has been shown to inhibit inflammatory mediators ${ }^{2,5-7}$.

In our study, groups with strontium therapy were significantly improved in terms of intestinal injury and peritonitis according to control and CLP group. In addition, if strontium therapy is initiated prophylactically before sepsis, peritonitis findings and small bowel mucosal injury are significantly less than strontium treatment after sepsis $(\mathrm{p}<0,05)$. This improvement may be due to the fact that the strontium has anti-inflammatory activity by blocking TNF- $\alpha$. (Graphic 1-2, Figure 1)

The plasma half-life of TNF-alpha secreted from monocytes and macrophages is several minutes. When endotoxin is administered intravenously to healthy individuals, TNF-alpha rises to a maximum at $2 \mathrm{~h}$ and returns to normal at $4 \mathrm{~h}^{14}$.

IL-1 reaches the peak level at 2 hours after ischemia and lipopolysaccharide exposure from all antigen presenting cells, such as monocytes, macrophages, and usually cleanses within 4 hours 15 .

At the sepsis, there is a study shows that the level of IL-6 increased after 2 hours of inflammatory stimulation, reached the highest level at 12 hours and became negative at 24 hours $^{16}$; Panero et'al ${ }^{17}$ indicated that IL- 6 height persisted for 48 hours and repetitive IL-6 measurements were more useful in early sepsis diagnosis. In a study conducted by Şahin et'al, mean IL-6 levels in sepsis cases were $56 \pm 58 \mathrm{pg} / \mathrm{ml}$. IL-6 levels were found to be above the mean value in 4 of the 7 dead patients and below the cut-off value in 2 of them, the possible cause of which is that the half-life of IL-6 is short 18 .

Interleukin-10 is mainly secreted by lipopolysaccharide-stimulated monocytes and $\mathrm{T}$ helper 2 lymphocytes, and also secreted by B lymphocytes and keratinocytes and is an important part of the inflammatory system. The half-life in circulation is about 2 hours. This cytokine shows antiinflammatory activity by suppressing the secretion of proinflammatory cytokines such as IL1 , IL-2, IL-6, IL-8, TNF- $\alpha$, GM-CSF ${ }^{19}$. In our study, TNF- $\alpha$, IL-1, IL-6 and IL-10 levels were not statistically different among each other. This may be due to the fact that we took blood samples on the 7 th day of sepsis and that the half-lives of these mediators are short.

\section{CONCLUSION}

This study was the first study to investigate the effect of strontium ranilate on peritonite, which was formed by cecal ligation and perforation in rats.

In this study, we believe that Strontium may decrease mortality and morbidity of patients with sepsis and most importantly, at risk of sepsis with prophylactic treatment. However, further studies in different phases are needed to conform our results.

Acknowledgements: Supported by the CUBAP (T-636)

Conflict of Interest: Authors declare no conflict of interests for this article

\section{REFERENCES}

1- Pieracci, F.M., Barie, P.S.Intra-abdominal infections. Curr. Opin. Crit. Care 2007;13, 440-9.

2- Topal F, Yonem O, Tuzcu N, et al. Strontium chloride: canit be a new 
treatment option for ulcerative colitis? Biomed Res Int 2014: 530687. doi:10.1155/2014/530687.

3- Collaert B. and Fischer C. "Dentine hypersensitivity: a review," Endodontics \& Dental Traumatology 1991; 7: 145-52.

4- Autio HKA, Scher I, and Morris MJ. "Therapeutic strategies for bone metastases and their clinical sequelae in prostate cancer," Current Treatment Options in Oncology 2012;13: 174-88.

5- Huang C, Li L, Yu X. et al. The inhibitory effect of strontiumdoped calcium polyphosphate particles on cytokines from macrophages and osteoblasts leading to aseptic loosening in vitro. BiomedicalMaterials 2014; 9, Article ID025010.

6- Yamaguchi M, Weitzmann MN. The intact strontium ranelate complex stimulates osteoblastogenesis and suppresses osteoclastogenesis by antagonizing NF- $\kappa \mathrm{B}$ activation.Molecular and Cellular Biochemistry 2012; 359: 399-07.

7- Buache E, Velard F, Bauden E et al. "Effect of strontium substituted biphasic calcium phosphate on inflammatory mediators production by humanmonocytes," Acta Biomaterialia 2012; 8: 3113-9.

8- Rittirsch D, Hoesel LM, Ward PA. The disconnect between animal models of sepsis and human sepsis. J Leukoc Biol 2007; 81: 137-43.

9- Simon $\mathrm{R}$, Wetzel $\mathrm{W}$, Winsey $\mathrm{K}$, et al. Supplemental dietary tyrosine in sepsis and acute hemorrhagic shock. Arch Surg, 1987; 122: 78-81.

10- Chui CJ, McArdle AH, Brown R, et al. Intestinal mucosal lesion in lowflow states.
A morphological, hemodynamic and metabolic reappraisal. Arch Surg 1970;101(4):478-83.

11- Parker SJ, Watkins PE. Experimental models of gram-negative sepsis. Br J Surg 2001; 88: 22-30.

12- Cavaillon JM, Annane D. Compartmentalization of the inflammatory response in sepsis and SIRS. J Endotoxin Res 2006; 12: 151-70.

13- Van der Wal JB, Jeekel J. Biology of the peritoneum in normal homeostasis and after surgical trauma. Colorectal Dis 2007; 9: 9-13.

14- Michie HR, Manogue KR, Spriggs DR, et al. Detection of circulating tumor necrosis factor after endotoxin administration. $\mathrm{N}$ Eng J Med 1988; 318: 1481-86.

15- Chowers Y, Cahalon L, Lahav M, et al. Somatostatin through its specific receptor inhibits spontaneous and TNF-alpha- and bacteria-induced IL-8 and IL-1 beta secretion from intestinal epithelial cells. $\mathrm{J}$ Immunol 2000, 15; 165: 2955-61.

16- Messer J, Eyer D, Donato L, et al. Evaluation of IL-6 and soluble receptors of TNF for early diagnosis of neonatal infection. J Pediatr 1996; 129: 574-80.

17- Panero A, Pacifico L, Rossi N, et al. IL-6 in neonates with early and late onset infection. Pediatr Infect Dis J 1997; 16: 370-5.

18- Şahin Y, Şahin DA. Yenidoğan sepsisinin erken tanisinda C-reaktif protein ve interlökin-6'nın rolü. Türk Pediatri Arşivi 2004; 39: 171-7.

19- Pérez Fernández R, Kaski JC. Interleukin10 and coronary disease. Rev Esp Cardiol 2002; 55: 738-50. 